\title{
Percepcja miejsc węzłowych w ujęciu kulturowym. Studium przypadku dzielnic zamieszkałych przez ludność żydowską w Polsce centralnej
}

\author{
Malgorzata Hanzl \\ Instytut Architektury i Urbanistyki Politechnika Łódzka, e-mail: mhanzl@p.lodz.pl
}

\begin{abstract}
Streszczenie: Sposób postrzegania miejskiej przestrzeni oraz zespół znaczeń, które ta przestrzeń przenosi, pozostaje różny w zależności od grupy odbiorców przekazu. Dla badania znaczeń oraz sposobu funkcjonowania miejskich przestrzeni na styku dwóch kultur zastosowano w niniejszym opracowaniu metodę bazującą na badaniach morfologii miasta oraz antropologii i analiz kultury. Studium przypadku podejmuje temat relacji pomiędzy strukturami urbanistycznymi zasiedlonymi w okresie przed drugą wojną światową przez społeczność żydowską, a aspektami życia codziennego właściwymi dla tej społeczności. Podczas gdy różnorodność stylów życia cechująca społeczność żydów polskich była w owym czasie znaczna, pewne cechy dają się klarownie wyodrębnić, szczególnie w odniesieniu do społeczności zachowującej tradycyjne formy życia społecznego. Cechy te wyraźnie przekładały się na formy struktur, gdzie omawiane grupy społeczne zamieszkiwały. Trzy główne obszary życia społecznego związane z trzema podstawowymi sferami życia były to: sfera życia religijnego, sfera życia domowego, codziennego oraz sfera życia zawodowego. Sfery te wyznaczały charakterystyczny sposób organizacji przestrzeni miejskiej, w szczególności tej o charakterze półprywatnym, zlokalizowanej wewnątrz kwartałów zabudowy. Ta specyficzna forma układu połączeń socjometrycznych wewnątrz i pomiędzy blokami zabudowy daje się wyróżnić niezależnie od formalnego sposobu kształtowania planów miast i miasteczek, które społeczność żydowska zamieszkiwała.
\end{abstract}

Słowa kluczowe: Morfologia miasta, antropologia, przestrzeń publiczna, kultura żydowska.

\section{Wprowadzenie}

Percepcja przestrzeni miejskiej oraz zakres przypisywanych im znaczeń różni się w zależności od przynależności kulturowej odbiorców miejskiego krajobrazu. Przeprowadzone badania, wykorzystujące $\mathrm{z}$ jednej strony dorobek metodologiczny antropologii architektury oraz analizę sfery znaczeniowej, z drugiej zaś podejście morfologii miasta, posłużyły poszukiwaniu odpowiedzi na pytanie jak możemy odczytać i zrozumieć struktury miasta patrząc przez pryzmat minionej kultury [1]. Podejście architektoniczne w morfologii miasta, reprezentowane przez badaczy szkół włoskiej oraz francuskiej, w centrum zainteresowania stawia formę struktur miejskich uwzględniającą trzeci wymiar i przekształcenia w szczegółowej skali budynków oraz pierzei ulic i placów. W tym ujęciu powiązania pomiędzy uwarunkowaniami społecznymi budowy miasta, a formami zabudowy opierają się przede wszystkim na analizie sfery znaczeniowej struktur miejskich. Podejście antropologii miasta bazuje z jednej strony na definicji sytuacji, rozumianej jako scena ludzkich aktywności [2]. 
Z drugiej zaś strony wykorzystuje znaczenie kontekstu urbanistycznego dla wzbogacenia interakcji międzyludzkich, w ten sposób udostępniając dodatkowy kanał komunikacji [3]. Szczególnie istotne są sposoby korzystania z miejskich przestrzeni i ich wzajemne powiązania. Ponadto przestrzenne rozmieszczenie znaków komunikuje treści, analogicznie do terytorialnych zachowań grup ludzi, które odzwierciedlają ich wewnętrzną organizację [4]. Przedmiotem zainteresowania $w$ tego rodzaju badaniach staje się forma przestrzeni zewnętrznych. Poza analizą przekazywanych treści oraz systemów powiązań między poszczególnymi fragmentami, badanie koncentrują się wokół cech takich jak kształt przestrzeni publicznych, półpublicznych, półprywatnych, ich forma i gabaryty odniesione do ludzkiej skali, czy wreszcie ich charakter, atmosfera.

Niniejszy artykuł podejmuje próbę scharakteryzowania niektórych z tych odmienności odnosząc uwagi natury metodologicznej do prezentowanego studium przypadku. Przedmiotem badania są struktury miejskie powstałe w okresie przedwojennym w wyniku zamieszkiwania i działalności w granicach dzisiejszych województw mazowieckiego i łódzkiego ludności żydowskiej. Niniejszy referat prezentuje wybrane wnioski z pracy badawczej na ten właśnie temat [1].

\section{Metodologia}

Oddziaływanie uwarunkowań społecznych i kulturowych na sposób kształtowania zabudowy miejskiej pozostaje w obszarze zainteresowania specjalistów reprezentujących szereg dyscyplin, w tym przede wszystkim: morfologię miasta, geografię historyczną, historię budowy miast oraz antropologię architektury. Przy czym analizy tła społecznego zawsze towarzyszyły badaniom w obszarze geografii historycznej [5], w tym również tym które reprezentują tzw. polską szkołę morfologii miejskiej. Ten nurt, o wyraźnie ugruntowanej już renomie, przynależy do tzw. szkoły Conzenowskiej, której nazwa wywodzi się od nazwiska jest twórcy M.R.G. Conzena [6]. Prace badawcze prowadzone były najobficiej w okresie po drugiej wojnie światowej, począwszy od lat sześćdziesiątych, i bazowały na dorobku morfologów niemieckich. Do tego nurtu, którego rozwój w okresie powojennym znaczyły prace Dziewońskiego [7], reprezentują w znakomity sposób badania autorów takich jak: Gołachowski [8], Pudełko [9, 10 i inne], Koter [11], Kulesza [12]. Przedmiotem zainteresowania badaczy tego nurtu stały się przede wszystkim plany miast średniowiecznych oraz ich ślady dające się wyodrębnić we współcześnie zachowanych układach podziałów własności i sieci ulicznej. Metoda stosowana przez badaczy kontynuowała myśl Conzenowską [5]. Kolejnym istotnym tematem stały się transformacje planów miast w czasach Klasycyzmu, a także pochodzące z późniejszego okresu przekształcenia planów miast przemysłowych (przykładowo: [13]). W metodzie Conzena [14] uwaga koncentrowała się na analizach planów miast na tle uwarunkowań ekonomicznych i społecznych. Metoda ta rozwijana była w późniejszym okresie obficie w obszarze kultury brytyjskiej przez badaczy takich jak np. Whitehand. Według Vernez-Moudon [15, str.4] badacze dążyli do wskazania wzajemnych powiązań łączących miasto, zamieszkującą je społeczność oraz dynamikę przekształceń jego struktur.

Odmienny sposób traktowania zagadnień analiz struktur miejskich odnajdujemy w pracach przynależących do tzw. włoskiej szkoły morfologii miasta, zapoczątkowanej przez dokonania S. Muratoriego. Reprezentowane tam podejście ma zdecydowanie bardziej architektoniczny charakter i opiera się na typologii struktur miejskich, która stanowi przedmiot analizy w ramach czterech poziomów odniesienia: budynku, dzielnicy, miasta oraz regionu. 
Kolejnym elementem właściwym tej szkole jest nacisk kładziony na wykorzystanie historii miejsca jako wątku niezbędnego do wzięcia pod uwagę przy tworzeniu projektów nowej zabudowy. Odniesienie do "historii w działaniu" ("storia operante") jest elementem przynależącym do warsztatu działań projektowych, nie wyłącznie analitycznych, stąd Gauthier i Gilliland [16] podkreślają raczej normatywny niż kognitywny charakter działań tej szkoły. Rezultaty łatwo zaobserwować w dziełach architektury, a także w pracach teoretycznych adeptów nurtu, w tym szczególnie reprezentatywne pozostaje twórczość Aldo Rossiego [17]. Wydziały Architektury we Włoszech słyną z niezwykle dokładnych analiz zabudowy, w tym indywidualnych budynków i ich planów.

Podobnie podejście architektoniczne przeważa wśród prac szkoły francuskiej morfologii miasta, której badania koncentrują się wokół przekształceń budynków i pierzei ulicznych, a także form ulic i placów, zarówno w odniesieniu do ich planu jak i analizy formy przestrzennej [18,19]. Darrin [18] wyróżnia dwa podstawowe prądy obecne w studiach szkoły francuskiej. Lavedan w swoich uznawanych za klasyczne pracach [20, 21, 22] zajmuje się rozwojem idei oraz dziejami myśli urbanistycznej oraz jej wpływem na kształt struktur miejskich. Podejście to zawęża obszar zainteresowania badań do tych elementów, które reprezentują nowe trendy, najczęściej implementowane poprzez interwencje realizowane przez włodarzy danego terenu. Drugi z trendów, zwany topograficznym, reprezentowany przez monumentalną analizę rozwoju zabudowy Paryża przez Poëte [23], zajmuje się badaniem miast oraz przekształceń struktur miejskich z uwzględnieniem kontynuacji czasu i miejsca. $\mathrm{W}$ ramach tego drugiego podejścia przedmiotem analizy stają się zatem nie tylko działania odgórne, ale wszelkie starania prowadzące do transformacji zabudowy, w tym również te realizowane przez samych mieszkańców.

Obok analiz struktur zabudowy per se, znaczny dorobek badawczy można również odnaleźć w obszarze analiz wzajemnych oddziaływań pomiędzy uwarunkowaniami życia społecznego i formami zabudowy i przestrzeni otwartych w miastach. Analizy tego rodzaju znajdujemy już w studiach Londynu przez Booth’a [24], uznawanych współcześnie za źródła historyczne, a także w pracach badaczy włoskich [25]. Bandini [26, str.133] wskazuje jednak na niedostatek precyzyjnie zdefiniowanej metodologii badań form struktur miejskich uwzględniających perspektywę nauk o społeczeństwie i kulturze. Brak ten w szczególności nie pozwala na analizę krajobrazu zurbanizowanego z uwzględnieniem warstwy informacyjnej, która dostarcza kontekstu sytuacyjnego. Tego rodzaju rozważania, pozostające w obszarze zainteresowań antropologii miasta, dotyczą szerzej społecznych uwarunkowań budowy miast, a w szczególności ich relacji z formami zabudowy które dostarczają tła i są źródłem znaczeń dla wydarzeń, które w miejskich przestrzeniach zachodzą [27]. Istotne dla zdefiniowana wzajemnych relacji krajobrazu miejskiego i aktywności mieszkańców pozostaje pojęcie sytuacji, rozumiane jako scena dla działań ludzkich [2]. Elementem tejże sceny jest kontekst urbanistyczny, funkcjonujący jako dodatkowy kanał informacyjny, który służy przekazywaniu znaczeń o charakterze sytuacyjnym [3].

Podobnie do zachowań przestrzennych ludzi, wskazujących na sposób organizacji grup społecznych, również rozmieszczenie znaków pozwala na komunikowanie treści [4]. Podobnie układ i wzajemne powiązania miejskich przestrzeni odgrywają ważną rolę w definiowaniu sposobu korzystania z tychże, co podkreślają Hillier i Hansen [28, str. 223-224], a także Marshall [29]. Kolejne cechy przynależne do obszaru analiz formy przestrzeni zewnętrznych: publicznych, półpublicznych, ogólnodostępnych, to ich kształt oraz odniesione do ludzkiej skali gabaryty, a także charakter lub atmosfera. Wśród autorów zajmujących się analizą form struktur miejskich w ujęciu zbliżonym do podejścia antropologii wymienić należy 
autorów takich jak Amos Rapoport [30]. Z kolei charakterystyka przestrzeni publicznych jest przedmiotem badań naukowców przynależących do tzw. szkoły portugalskiej morfologii miasta. Wśród znanych badaczy, piszących o kwestiach postrzegania przestrzeni zewnętrznych, wymienić należy ponadto Kevina Lynch'a [31], twórczość którego klasyfikowana jest na pograniczu prac o charakterze normatywnym i kognitywnym [16].

W ostatnim okresie nastąpił bardzo istotny rozwój badań nad morfologią miasta, zapomnianych nieco w czasach modernizmu. Analizy form zabudowy i przestrzeni publicznych stają się ważnym elementem, i to zarówno jako składowa badań geografii historycznej, jak i w pracach twórczych, o charakterze normatywnym, przy definiowaniu zasad kształtowania nowej zabudowy. Trend ten jest wyraźny również w Polsce, w tym w szczególności w działaniach Sekcji Morfologii Urbanistycznej krakowskiego Oddziału PAN [32].

W powyższym, pomimo że dość pobieżnym, przeglądzie głównych trendów badań nad morfologią miejską dostrzec można opozycję pomiędzy charakterystyką struktur odzwierciedlających główne trendy budowy miast danej epoki, a więc budowanych w wyniku procesów o charakterze odgórnym, realizowanych przez organa władzy, a badaniami określanymi mianem topograficznych, w których zainteresowanie koncentruje się na zmianach zachodzących w obrębie danego obszaru w danym czasie [18]. Przekształcenia które są przedmiotem analizy w tym drugim przypadku obejmują wtedy zarówno te, które wynikają z planowania o charakterze odgórnym, jak i takie które są rezultatem działań oddolnych, do których można z pewnym przybliżeniem zastosować termin "wernakularyzm”. Jednocześnie ze względu na skalę zachodzących przeobrażeń, niejednokrotnie wykraczającą poza ramy właściwe dla architektury wernakularnej, a także ze względu często na brak dokumentacji projektowej, czyli łatwych do pozyskania źródeł historycznych, procesy tego rodzaju nie są uwzględniane w charakterystyce zachodzących transformacji. Skala oraz ranga tego rodzaju procesów doczekała się opisu w metodologii badawczej dziedziny zajmującej się zagadnieniami złożoności (complexity) w planowaniu [33]. Niniejsze studium przypadku, podobnie jak inne prace autorki [przykładowo 34,1], koncentrują się na tym właśnie podejściu.

\section{Studium przypadku}

Przedmiotem analizy w ramach niniejszego studium przypadku uczyniono wzajemne oddziaływanie pomiędzy formami zabudowy i przestrzeni zewnętrznych zamieszkiwanymi w okresie przed II wojną światową przez społeczność żydowską, a codziennym życiem tejże społeczności. Zakres terytorialny badania ograniczył się do miast i miasteczek zawartych w obecnych granicach administracyjnych województw łódzkiego i mazowieckiego. Jednym z naczelnych tematów okazała się dynamika przemian kulturowych zachodzących w obrębie tejże społeczności, pokazana na tle procesów urbanizacji i industrializacji wieku dziewiętnastego i początku wieku dwudziestego.

Przemiany zachodzące w obrębie układów miejskich w tym okresie, wywołane zarówno przez ekspansję miast na skutek rozwoju przemysłu, w tym szczególnie tekstylnego w Królestwie Polskim, jak również będące pochodną zmian w działaniu administracji terytorialnej, stały się kanwą na której zapisały się procesy migracji ludności żydowskiej. Społeczność żydowska, wywodząca się zarówno z obszaru Polski, jak i zmuszona do migracji z terytorium ówczesnej Rosji, charakteryzowała się w owym czasie znaczną różnorodnością stylów życia. Mozaika wynikająca przede wszystkim ze stopnia akulturacji z jednej strony lub przywiązania do tradycji i religii przodków z drugiej, ale również z obszaru pochodzenia, poglądów indywidualnych, poziomu wykształcenia i co za tym idzie wykonywanego 
zawodu i majętności, przekładała się bezpośrednio na różnorodność miejsc, gdzie Żydzi mieszkali.

Analizy rozmieszczenia społeczności żydowskiej oraz struktur miejskich które zamieszkiwali pozwoliły na przedstawienie wniosków odnośnie form zabudowy i przestrzeni otwartych i właściwych im znaczeń [1]. W ramach badania prześledzono rozwój zabudowy dzielnic żydowskich na tle zmieniających się uwarunkowań budowy miast w omawianym obszarze. Ponadto poddano szczegółowej analizie dzielnice zamieszkałe przez społeczność żydowską w czterech wybranych miejscowościach: Łodzi, Brzezinach, Górze Kalwarii oraz Otwocku. Na łamach niniejszej publikacji zaprezentowano streszczenie najważniejszych wątków dotyczących skali lokalnej.

\section{Rezultaty badania - uwarunkowania kulturowe i społeczne}

Cechą szczególnie charakterystyczną dla społeczności żydowskiej zamieszkującej przed wojną rejon Łodzi i Warszawy była jej różnorodność. Procesy industrializacji i intensywnej urbanizacji wieku dziewiętnastego i początku wieku dwudziestego i związane z nimi przemiany społeczne doprowadziły do sytuacji, w której tradycyjny model funkcjonowania społeczności żydowskiej, bazujący na wspólnocie o charakterze religijnym, zaczął być podważany. Kolejnym przyczynkiem dla zmian był rozwój żydowskiej Haskali promującej nowe, oświeceniowe prądy religijne szczególnie wobec podatnego gruntu jaki znalazły w kręgach żydowskiej burżuazji przemysłowej oraz inteligencji. W tym samym czasie, niejako w reakcji do nowych trendów, dotychczasowe przywiązanie do tradycji zaczęło nabierać cech ortodoksyjnych. Mozaiki postaw religijnych dopełniały ponadto obecność ruchów chasydzkich, w znaczący sposób oddziałujących na postawy mas ludności żydowskiej oraz na ich styl życia czy sposób spędzania wolnego czasu [35]. Pomimo ograniczonego miejsca na bardziej wnikliwy opis różnorodnych postaw i stylów życia wśród społeczności Żydów polskich zamieszkałych przed wojną w centralnej Polsce, koniecznym jest dostrzeżenie jej oddziaływania na formy struktur przestrzennych przez nią zajmowanych.

Elementem szczególnie istotnie oddziałującym na formowanie struktur miejskich pozostaje kultura życia codziennego. Wśród najważniejszych cech społeczności wpływających na sposób codziennego funkcjonowania wymienić należy: status materialny mieszkańców, wyznawaną religię lub przynależność do odłamu religijnego, wykonywane zawody lub przeważający sposób zarobkowania danej społeczności, a także dotychczasowe migracje mieszkańców i ich pochodzenie.

Początkowo, poczynając od rozbiorów Polski, możliwości zarobkowania ludności żydowskiej powiększały się. Dotyczyło to najbardziej ludności zamieszkującej niewielkie miasteczka, przeważnie zaangażowanej wraz z całymi rodzinami w dzierżawę tawern, browarów oraz produkcję napojów alkoholowych [36]. Ta grupa zawodowa, która nadal w końcu osiemnastego wieku liczyła około $25 \%$ ogółu żydowskiej populacji, reprezentowała cechy społeczności miejskiej oraz utrzymywała bezpośrednie kontakty z kahałem w pobliskich miejscowościach [37, str.208]. W następstwie zmian prawnych wdrożonych przez państwa zaborcze ${ }^{1}$ Żydzi z jednak strony uzyskali prawa obywatelskie, z drugiej jednak strony nałożone na nich dodatkowe obciążenia fiskalne oraz obostrzenia działalności zarobkowej, przykładowo zakaz produkcji napojów alkoholowych, a później dodatkowo

1 W obszarze późniejszego Księstwa Warszawskiego było to tzw. „Generalne urżądzenie Żydów w prowinyach Prus Południowych i Nowo-Wschodnich”, wydane 17 kwietnia 1797 roku w Berlinie. 
bardzo wydłużona służba wojskowa, istotnie obniżyły możliwości ekonomiczne znacznej części ludności żydowskiej. W późniejszym okresie pojawiały się kolejne ograniczenia. Początkowo nadane Żydom w liberalnej Konstytucji Księstwa Warszawskiego prawa cywilne zostały jednak wkrótce odsunięte w czasie a następnie całkiem uchylone. Konstytucja Królestwa Polskiego odmawiała Żydom pełni praw cywilnych, poza nielicznymi grupami uprzywilejowanymi majątkowo oraz zasymilowanymi, oraz po potwierdzeniu decyzją władz rosyjskich. Jak podaje Eisenbach [38, str.142] regulacje prawa osiedlania się Żydów w latach sześćdziesiątych dziewiętnastego wieku pozwalały na ich zamieszkiwanie jedynie w 246 spośród ogólnej liczny 453 miast i osad Królestwa Polskiego. Dopiero dekret z roku 1862 roku przyznający ludności żydowskiej pełnię praw obywatelskich spowodował znaczną poprawę ich sytuacji, wprowadzając swobodę osiedlania, zrównanie w podatkach oraz dostępność wykonywania wybranych zawodów.

Równocześnie dzięki industrializacji wyłoniły się zupełnie nowe zawody czy też obszary aktywności, co dotyczyło szczególnie Warszawy i Łodzi, a także terenów z tymi miastami sąsiadujących. Stosując jako kryterium podziału status materialny wyodrębnia się wśród nich kilka grup: (1) nieliczna i majętna burżuazja; (2) inteligencja, której rozwój można zaobserwować poczynając od mniej więcej połowy XIX w.; (3) handlowcy; (4) wytwórcy i rzemieślnicy wraz szeroką rzeszą zatrudnianych czeladników, pomocników, etc; (5) pracownicy sezonowi i niewykwalifikowani, tragarze, etc. Żydzi jedynie sporadycznie znajdowali zatrudnienie w dużych zakładach przemysłowych, jako że zmuszałoby to do nieprzestrzegania reguł szabatu. $Z$ tego względu grupa najbardziej liczna i jednocześnie najbiedniejsza, odmiennie niż w przypadku społeczności polskiej, składała się przeważnie z drobnych handlarzy oraz z niewykwalifikowanych pracowników sezonowych.

Kolejnym obok rodzaju źródła utrzymania i poziomu dochodów ważnym przyczynkiem dla wyboru miejsca zamieszkania oraz jego późniejszego sposobu zagospodarowania było miejsce z którego dana osoba czy rodzina się wywodziła. W ramach tej kategorii największą rolę odegrała imigracja Żydów z Rosji w drugiej połowie wieku dziewiętnastego. Majątki oraz kontakty handlowe przybyszów przyczyniły się do rozwoju gospodarczego miejscowości w których się osiedlali. Przykładem mogą być tutaj Brzeziny pod Łodzią, gdzie dzięki żydowskiemu osadnictwu nastąpił gwałtowny rozwój krawiectwa. Także w Łodzi potencjał oraz aktywność gospodarcza przybyłych umożliwiły liczne inwestycje, a także znaczne powiększenie obszaru zajmowanego przez żydowską społeczność. Ponadto w obu wymienionych miejscowościach umocnienie bazy ekonomicznej pozwoliło na wznoszenie budynków murowanych na skalę wcześniej trudną do osiągnięcia.

Równie ważnym czynnikiem dla analizy fragmentów miast zamieszkałych przez Żydów był intensywny wzrost demograficzny, szczególnie poczynając od nadania Żydom w roku 1862 pełni praw publicznych. Już wcześniej obserwowana migracja do wielkich ośrodków miejskich znacznie się wtedy zintensyfikowała. Sytuacja zaczęła zmieniać się po fali pogromów, która rozpoczęła się w 1881, i która rozpoczęła masową emigrację do USA, Palestyny, i innych krajów. W jej efekcie, a także na skutek zmniejszenia liczby urodzeń wobec biedy wywołanej pierwszą wojną światową, a później braku stabilności ekonomicznej, odsetek ludności żydowskiej zmalał z 14\% w roku 1880 do około 9,8\% w roku 1931. Prezentowana poniżej analiza rozmieszczenia ludności żydowskiej w miastach i miasteczkach bazuje na rezultatach spisu powszechnego przeprowadzonego w roku 1921 (Rys. 1). 


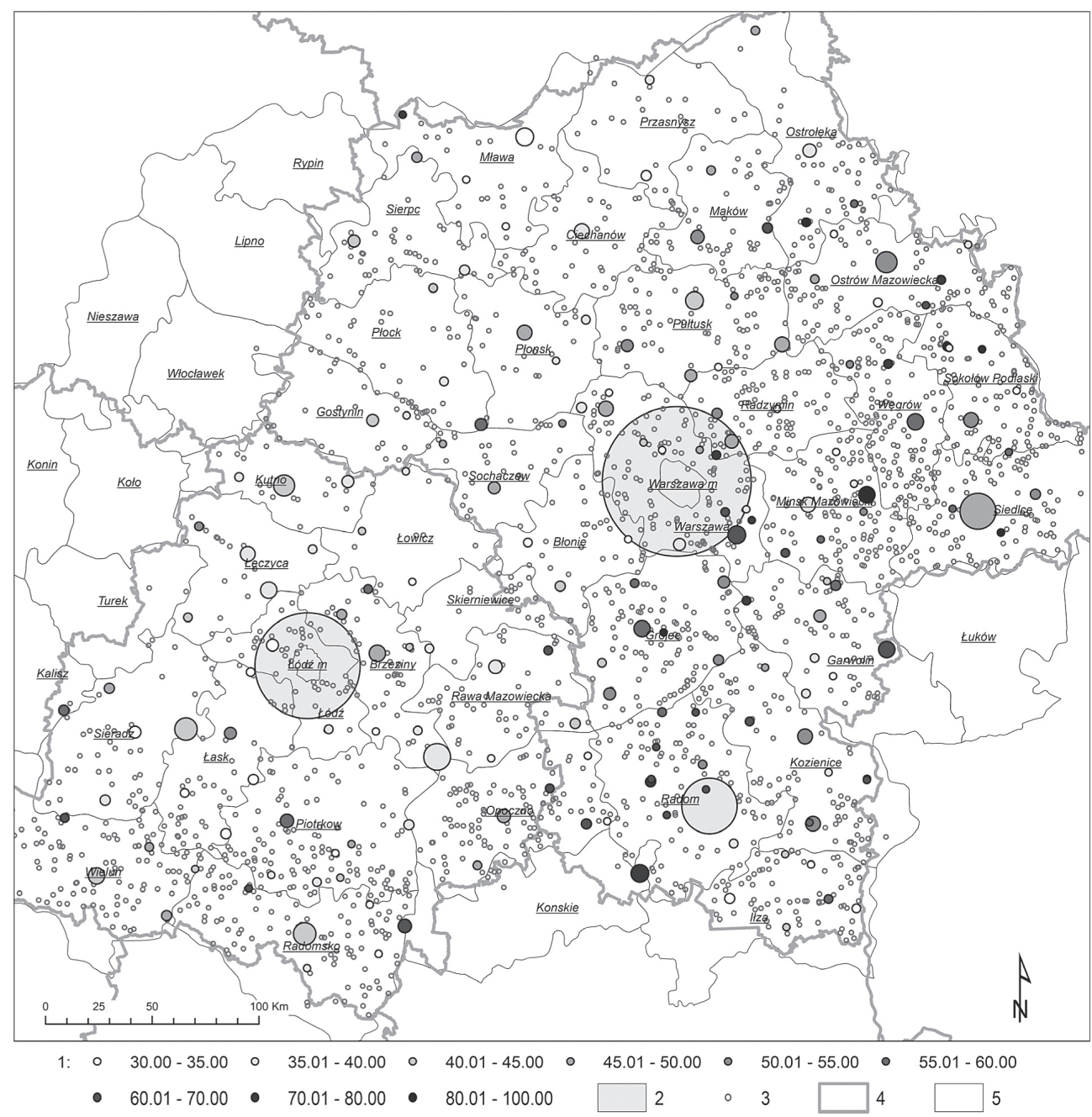

Rys. 1. Osiedla gdzie liczba żydowskich mieszkańców wynosiła co najmniej 50 osób oraz gdzie stanowili oni nie mniej niż 30\% populacji [39]. 1. udział żydowskich mieszkańców w ogólnej liczbie ludności, wielkość punktu odpowiada wielkości populacji, 2. centra regionalne: Warszawa, Łodź, 3. pozostałe miejscowości gdzie mieszkali Żydzi, 4. współczesne granice województw, 5. przedwojenne granice powiatów

Dzięki nałożeniu wielkości populacji w poszczególnych miejscowościach, jej rozmieszczenia i dynamiki zmian ze strukturą tej społeczności, zaobserwować można występowanie grup charakteryzujących się wyraźnie odmienną kulturą życia codziennego. Różnorodność nasila się poczynając od drugiej połowy wieku dziewiętnastego, wraz z uzyskaniem przez Żydów pełni praw obywatelskich, które pozwoliły jednostkom bardziej przedsiębiorczym i dynamicznym oraz dysponującym pewnym kapitałem na podjęcie działalności gospodarczej lub zdobycie wykształcenia. Poprawą sytuacji materialnej wiązała się zazwyczaj również ze zmianą miejsca zamieszkania i migracją do dzielnicy uważanej za lepszą. Dotyczyło to wszystkich warstw społecznych, zarówno tych przywiązanych do tradycyjnej kultury 
i obyczajowości, jak i tych które przyjęły bardziej zmodernizowany światopogląd. Trzeba też zauważyć, że ścisłe związki utrzymywane przez rodziny kultywujące tradycyjną obrzędowość z gminą żydowską powodowały ich zamieszkiwanie w pobliżu synagogi. Warstwy biedniejsze, bez różnicy światopoglądu, zamieszkiwały w dzielnicach uważanych za tradycyjne. Spośród badanych miast omawiana dynamika przestrzenna najbardziej widoczna jest w Łodzi, z racji wielkości społeczności żydowskiej. Analiza lokalizacji firm i instytucji przynależących do tej grupy wskazuje, że wraz z akumulacją kapitału znaczenie wcześniejszych barier przestrzennych malało, jak np. w przypadku zakładów Oskara Kohna. Cechą stałą pozostało za to rozwarstwienie w przestrzeni. Jego źródeł szukać należy jeszcze w okresie funkcjonowania wydzielonego rewiru, kiedy to poza jego obszarem mogły mieszkać rodziny charakteryzujące się wysokim statusem materialnym i zasymilowane. Konsekwencją takiej stratyfikacji było wykształcenie się stref o odmiennych cechach przestrzennych, przy czym w rejonach gdzie poziom akulturacji lub asymilacji był wyższy sposób organizacji przestrzeni i zabudowy upodabniał się do obszarów o innej niż żydowska przynależności kulturowej. Przy czym niewiele było tak naprawdę miejsc zamieszkiwanych wyłącznie przez ludność żydowską, szczególnie akulturacja sprzyjała integracji kulturowej.

W dalszej części artykułu zajmiemy się skalą dzielnicy, przy czym przedmiotem zainteresowania uczynimy formy przestrzenne właściwe dla kultury tradycyjnej. Takie podejście uzasadnia wyższe niż gdzie indziej natężenie cech właściwych danej społeczności, obserwację tę potwierdza teoria Hall'a [40] w myśl której rejony o wysokim stopniu zdefiniowania kontekstu, a więc te przynależące do kultury tradycyjnej, cechuje bogatszy zbiór znaczeń przypisanych do elementów środowiska miejskiego. W miejscach właściwym kulturom o niższym stopniu definicji kontekstu, czyli zasymilowanym lub podlegającym akulturacji zestaw znaczeń i uwarunkowań ulega osłabieniu i nabiera charakteru bardziej uniwersalnego.

\section{Rezultaty badania - forma zagospodarowania przestrzeni, lad przestrzeni}

Przeprowadzona analiza dotyczyła cech formalnych przestrzeni zewnętrznych, w tym: skali wnętrz urbanistycznych, rytmów, urozmaicenia (pofałdowania) ścian wnętrza, wariacji linii sylwety placu lub ulicy. Badanie pozwoliło wykazać, że w wyniku nakładania się wzorców kulturowych następowało wymieszanie upodobań estetycznych. Jednocześnie z dywersyfikacją potencjału ekonomicznego inwestorów i najemców w ramach tego samego obszaru dawało to w efekcie znaczną różnorodność form, przykładowo wzdłuż jednej ulicy zabudowa różniła się gabarytami, szczególnie wysokością, sposobem konstrukcji, stosowanymi materiałami, standardem wykończenia oraz obfitością lub brakiem detalu architektonicznego.

Opisy dzielnic żydowskich obfitują w stwierdzenia odnoszące się od cech, które im przypisywano niemal tradycyjnie, jak: przeludnienie, brak ciągłości pierzei ulicznych, chaotyczne rozmieszczenie budynków, niekontrolowane przekształcenia parcelacji, etc [41, str.63]. Źródłem tych, nacechowanych zazwyczaj negatywnie stwierdzeń, były poglądy utrwalone od czasów opracowań mających na celu przekształcenia miast podejmowane jako element szerszych działań prowadzonych dla odtworzenia, a wcześniej umocnienia polskiej państwowości poprzez zwiększenie roli władzy państwowej i odejście od przestarzałych struktur feudalnych. Analizy te, osadzone w filozofii Oświecenia, organizację przestrzeni inną niż oparta na układzie geometrycznym postrzegały bardzo krytycznie. W opisach dzielnic zamieszkałych przez Żydów często była mowa o braku ładu, nieporządku czy wręcz bałaganie. 
Jednocześnie przyczyn negatywnych zjawisk doszukiwano się głównie w biedzie i przegęszczeniu tych obszarów. Nie negując tych problemów, należałoby jednak zwrócić uwagę, że podobnie zły stan utrzymania budynków dotyczył również innych miejsc nie przynależących do Żydów, a zamieszkałych przez miejską biedotę. Na postrzegane wrażenie "bałaganu” składała się, jak można się domyślać, odmienna percepcja ładu przestrzennego u ludności żydowskiej i polskiej. Przykładowo przekształcenia podziału działek oraz form zabudowy, które stopniowo prowadziły do odkształceń linearnego przebiegu fasad ulicznych, zazwyczaj wiązano z działaniami o charakterze spekulacyjnym oraz z niedostatkiem dbałości o porządek. Tymczasem tego rodzaju odkształcenia, wyraźnie czytelne w planach miast zamieszkałych przez ludność żydowską, winny być traktowane jako zagadnienie kulturowe, przynależne odrębnej organizacji społecznej, analogicznie do analiz planów miast w sytuacji przekształceń zachodzących wobec zmiany profilu kulturowego mieszkańców.

\subsection{Układ przestrzeni zewnętrznych}

Hillier i Hanson [28, str.27] traktują wzorce zachowań i sposób wykorzystania przestrzeni właściwe danej społeczności jako elementy warunkujące kształt struktur miejskich, w szczególności wpływające na formy przestrzeni zewnętrznych. Sposób użytkowania przestrzeni właściwy dla tradycyjnej społeczności żydowskiej był wyraźnie odmienny od zastanego tła kulturowego. Wraz z napływem Żydów, organizacja przestrzeni ewoluowała od bardziej rozdrobnionej i linearnej, w stronę układów zogniskowanych wokół miejsc istotnych dla życia codziennego tej społeczności. Miejsca te można zaklasyfikować do trzech kategorii:

- sacrum - zespół obiektów zgromadzonych wokół synagogi lub bożnicy, dom studiów (beit midrash), łaźnię rytualną, i inne budynki właściwe kultowi, przy czym chasydzi grupowali się wokół własnych odrębnych domów modlitwy, ze względu na odrębność liturgi, podobnie wspólnoty dobroczynne lub zawodowe często posiadały osobne domy modlitwy;

- profanum - przestrzeń rynku, wraz z otaczającymi ulicami, węzeł wymiany produktów wytwórczości i miejsce działalności handlowej, miejsce wokół którego ogniskowała się działalność zarobkowa;

- domus - poczynając od dziewiętnastego wieku reprezentowanego przez dziedziniec, podwórko kamienicy miejskiej.

Analiza podziałów własności i ich zmian w czasie, a w szczególności układów powiązań pomiędzy poszczególnymi parcelami potwierdza powyżej opisaną organizację przestrzeni. Pozycja wspólnoty religijnej w organizacji społeczności żydowskiej, utrwalona historycznie i reprezentowana przez władze kahalne, pozostawała przez wieki silna i niezależna od otaczającego miasta, nawet w sytuacji daleko idącej integracji i dbałości o potrzeby całej miejskiej społeczności. Ta odrębność znajdowała odbicie w organizacji przestrzeni, z wewnętrznym systemem połączeń wewnątrz bloków zabudowy. Charakter przestrzeni wewnętrznych podwórek i dziedzińców postrzegany jako nieuporządkowany i nieprzyjazny dla przybyszów z zewnątrz, dla Żydów, jak wynika z licznych opisów w literaturze, reprezentował miejsca swojskie, służące jako rozszerzenie mieszkań oraz jako przestrzeń wewnętrznej cyrkulacji. Potwierdzeniem powyższej obserwacji może być zwyczaj ustalania tak zwanych eruwim, służących wydzielaniu przestrzeni prywatnej, w ramach której dozwolone było przenoszenie przedmiotów w czasie Szabatu. Dla realizacji wydzielenia wykorzystywano już obecne w danej lokalizacji krawędzie, przykładowo mury czy ściany budynków, lub też montowano specjalne łańcuchy albo sznurki, których zadaniem było ustalenie w sposób fizyczny granicy wydzielenia. 


\subsection{Sposób realizacji przekształceń}

Badania sposobu w jaki następują przekształcenia układów miejskich są jednym z naczelnych tematów zainteresowania morfologii miasta $[14,42]$. W przypadku zmian zachodzących w sposobie organizacji przestrzeni, o których mowa powyżej, zachodziły one w sposób ewolucyjny. Jednocześnie jednak, niezależnie od pierwotnego sposobu rozplanowania miejscowości docelowy układ charakteryzował się zbliżonymi cechami. Najczęstsze lokalizacje preferowane przez ludność żydowską to te w bezpośrednim sąsiedztwie rynków i placów targowych, w centrach miast o proweniencji średniowiecznej. W takich miejscach adaptacja dla potrzeb dziewiętnastowiecznej urbanizacji następowała bez znaczących przekształceń pierwotnej parcelacji, poprzez wymianę zabudowy, zazwyczaj na murowaną, a także poprzez rozłożoną w czasie transformację organizacji połączeń wewnątrz bloków zabudowy mającą na celu zaspokojenie potrzeb bieżących. Ewolucyjny charakter zmian, który cechował te działania, wpływał na to że zazwyczaj trudno było w oczywisty sposób zdefiniować ich charakter. Często ograniczały się one do wprowadzenie pojedynczej nowej ulicy bądź przejścia, w ograniczonym zakresie zmieniając układ ogólnodostępnych przestrzeni publicznych. Przy okazji wymiany zabudowy następowało natomiast dogęszczanie już istniejących struktur, zwiększanie ich intensywności, ponadto wprowadzano drugą linię zabudowy, a także stopniowo urozmaiceniu ulegała linia brzegowa ulicy.

Analogiczne przekształcenia zachodziły w sytuacji miast doby baroku (przykładowo Góry Kalwarii), oraz układów klasycystycznych. W przypadku układów geometrycznych okresu klasycyzmu (w Łodzi Nowego Miasta, w sąsiedztwie Placu Wolności i ulicy Nowomiejskiej) system wewnętrznych pasaży i podwórek stanowił uzupełnienie formalnych układów przestrzeni placów i ulic. Ta znacznie bardziej zagęszczona sieć powiązań służyła trzem wymienionym powyżej sferom aktywności, w sposób częściowo jedynie nakładający się z systemem przestrzeni publicznych użytkowanych przez ogół mieszkańców.

\subsection{Organizacja przestrzeni styku}

Część treści odbieramy w sposób świadomy za pośrednictwem znaków przypisanych do obiektów przestrzeni miejskiej rozumianych w ramach danego kontekstu kulturowego [27]. Informacja o funkcjach przestrzeni miejskich jest dostarczana przede wszystkim dzięki obecności budowli i instytucji spełniających różne role w życiu danej społeczności. Równolegle do obiektów stałych, takich jak budynki, rolę komunikowania pożądanych dla danego miejsca zachowań pełnią obiekty częściowo trwałe, takie jak ogłoszenia, mała architektura, etc, a także nieformalne, zmienne. Działalność usługowa i handlowa pozostaje najłatwiejsza do odczytania, szczególnie że grupy odbiorców z nich korzystających zazwyczaj nie były pochodzenia żydowskiego. Jeśli wymagania handlu zewnętrznego narzucały potrzebę rozległych otwartych przestrzeni, były one zastawiane przez stoiska i kramy, zazwyczaj uporządkowane według oferowanych towarów, jednak wciąż konkurujące o uwagę przechodniów. W przypadku jeśli handel zajmował też partery okolicznych kamienic, przyjmowały one podobne cechy. Zazwyczaj podłoga takich wnętrz miejskich pokryta była nawierzchnią utwardzoną, dla uniknięcia błota. Nie było zieleni, drzewa, trawa czy krzaki nie mogłyby przetrwać w takich warunkach. Kramy miały zazwyczaj zadaszenie, często dotyczyło to również krytych galerii handlowych. W sklepach zlokalizowanych w parterach okolicznych kamienic wystawy konkurowały o uwagę, podobnie do wolno-stojących kiosków w rynku.

Bardzo racjonalna organizacja przestrzeni, ograniczona jej ilość bez określonego przeznaczenia, oraz częste nakładanie się i synergia różnych działań w tym samym miejscu 
dopełniały obrazu. Przestrzeń handlu nie ograniczała się do głównego placu, rozciągała się również na sąsiednie ulice i pasaże. Ulice żydowskie pełne były reklam, stojaków, zewnętrznych kramów, etc. Często przesunięte ku środkowi chodnika stelaże przyciągały uwagę przechodniów, niekiedy nawet, choć rzadko, podświetlane w nocy. Częściej do zatrzymania skłaniały okrzyki kupców i ich asystentów. Ulice i place handlowe razem z sąsiadującymi podwórzami bywały zazwyczaj opisane jako zatłoczone i zapchane towarami. Dostatek przestrzeni obrzeżnej, dzięki urozmaiceniu linii brzegowej na skutek między innymi braku niektórych frontów kamienic, ułatwiał lokalizację urządzeń zewnętrznych służących sprzedaży, jak również pozwalał na aktywność handlową.

\subsection{Uwarunkowania proksemiczne}

Niezależnie od przekazu o cechach użytkowych, informującego o ustalonych w obrębie danej kultury formach aktywności, dalsze cechy przekazywane były za pomocą formy przestrzeni fizycznych: poprzez jej skalę, rozmieszczenie elementów, rytmy, sposób formowania fasad, typy zadaszeń i nawierzchni, układ i formę reklam, a także inne obiekty składowe przestrzeni zewnętrznych miasta. Ta częściowo pozostająca poza świadomą percepcją forma komunikacji, która odbywała się za pośrednictwem wewnętrznej organizacji elementów przestrzeni publicznych tworzyła specyficzny dla tradycyjnych dzielnic żydowskich ład przestrzeni. Zrozumienia natury powiązań między wzorcami zachowań właściwymi danej kulturze, a środowiskiem życia człowieka dostarczają badacze zajmujący się proksemiką [40, 43], według których zachodzi relacja pomiędzy dystansami osobowymi jako cechą komunikacji, a skalą przestrzeni. W przypadku społeczności żydowskiej wielkości te musiały być mniejsze niż u społeczności polskiej, co potwierdza wąskość ulic, a w szczególności przejść, pasaży, zaułków w dzielnicach żydowskich. Zawężenie przestrzeni otwartych, a także przyzwolenie na ich dodatkowe zajmowanie przez składowanie tam rozmaitych elementów było charakterystyczne dla tej kultury. Szczupłość dostępnego miejsca powodowała, że wszystkie przestrzenie, nawet te najmniejsze, były intensywnie użytkowane, często zatłoczone i różne aktywności nakładały się na siebie. Ponadto wąskość niektórych ulic i wewnętrznych pasaży oraz obecność załamań fasady dostarczały okazji do angażowania się w bezpośrednie relacje międzyludzkie.

Środowisko miejskie, które zgodnie z teorią Hillier'a [44] postrzegane jest jako sieć połączeń, w której szersze i bardziej zintegrowane oraz eksponowane ulice zyskują wyższą rangę, w percepcji osób przynależnych do tradycyjnej kultury żydowskiej odbierane było jako zewnętrzne, co potwierdzają liczne opisy literackie. Szczupłość wewnętrznych pasaży oraz liczne krzywizny fasad pozwalały na zamknięcie perspektyw i zdefiniowanie wnętrz przestrzeni wewnątrz kwartałów. Żydzi zwykli budować własną sieć połączeń, wzbogaconą o przejścia wewnątrz bloków zabudowy, i nakładającą się na ogólnodostępną sieć ulic i placów. Przestrzeń ta miała wyraźnie dośrodkowy charakter. W przypadkach mniejszych kwartałów, na przykład w łódzkiej dzielnicy Bałuty, w jej części zbliżonej do Starego Miasta, niektóre spośród ulic funkcjonowały jako elementy układu wewnętrznego, rzadko odwiedzane przez przybyszów z zewnątrz, również ze względu na formę fizyczną: wąskość, krętość.

Fragmenty miasta czy bloki zabudowy przynależące do Żydów nie były jednak nigdy całkowicie zamknięte. Wręcz przeciwnie, ich strefa obrzeżna o wyraźnie funkcjonalnych charakterze handlu, wytwórczości i usług, zapraszała przechodniów, również dzięki urozmaiconej linii brzegowej. Odmiennie życie codzienne, a także inne aktywności społeczne i w szczególności funkcje kultu religijnego, szukały izolacji wewnątrz kwartałów. Wzorce opisane powyżej zmieniały się wobec akulturacji społeczności żydowskiej. Szczególnie dotyczyło 
to budowli sakralnych, które nabierając cech dominant we wnętrzach miejskich upodabniały się do chrześcijańskich kościołów.

\section{Podsumowanie}

Przeprowadzone analizy wykazały zachodzenie relacji, o których piszą Hillier i Hanson [28, str.27], pomiędzy wzorcami zachowań właściwymi odmiennym kulturom i grupom etnicznym, a formą przestrzeni zewnętrznych. Zróżnicowanie morfologii struktur zaistniało wszędzie tam gdzie mieliśmy do czynienia z heterogeniczną społecznością, co cechowało przed wojną niemal ogół miast i miasteczek centralnej Polski. Pomimo specyfiki odrębnej dla każdej miejscowości ze względu na uwarunkowania rozwoju historycznego, w tym własnościowe, specjalizację zawodową czy choćby lokalizację, można wyodrębnić wątki przestrzenne oraz szczególną konstytucję form fizycznych, która powtarzała się wszędzie tam gdzie występowała tradycyjna kultura żydowska. Wśród cech charakterystycznych należy przede wszystkim wskazać na intensywność cech typowo miejskich, w tym wyższe niż gdzie indziej gęstości zaludnienia oraz zabudowy, a także występowanie licznych relacji społecznych. Szczupłość miejsca powodowała synergię różnorodnych aktywności w tej samej przestrzeni. Ograniczona powierzchnia lokali i niedostatek miejsca na zaspokojenie wszystkich codziennych czynności domowych skutkował realizacją części z nich w przyległych podwórkach, które przez to stawały się niejako częścią strefy domu. Analogicznie działania o charakterze komercyjnym rozszerzały się na otaczające rynki i place targowe podwórka i pasaże, niekiedy zajmując znaczne obszary. Wszystkie te wzajemnie nakładające się rodzaje aktywności znacznie zwiększały stopień wykorzystania przestrzeni zewnętrznych, często doprowadzając do jej zatłoczenia. Wspólne korzystanie z przestrzeni zewnętrznych dla realizacji różnych celów stymulowało życie dzielnicy i generowało tworzenie relacji społecznych. Taka forma użytkowania przestrzeni czyniła ją wielofunkcyjną, a wielowymiarowość kultury codziennego funkcjonowania miejsc miała znaczenie dla ich aranżacji i typowego zbioru znaczeń, powiązanych z nią, powtarzalnych w różnych zajmowanych przez ludność żydowską lokalizacjach. Obok samej gęstości skutkowało to zdecydowanie bardziej miejskim charakterem dzielnic żydowskich.

Habitus, rozumiany jako zespół struktur miejskich i sytuacji społecznych, odzwierciedlających właściwe im zwyczaje i praktyki dnia codziennego [45, str. 247; 21, str.160), stał się w przypadku społeczności żydowskich w centralnej Polsce zapisem tychże praktyk. Analiza zachowanych do dziś miejsc uzupełniona o ich tło kulturowe stwarza możliwość odczytania dawnych sposobów funkcjonowania i relacji społecznych. Zestawienie ze sobą odmiennych sposobów funkcjonowania przestrzeni zewnętrznych oraz analiza przekształceń zabudowy i parcelacji pozwoliły wyłonić zbiór cech właściwych dla tradycyjnej kultury żydowskiej w Polsce centralnej. Badanie niniejsze wymaga kontynuacji dla uzyskania pełnego obrazu rozwoju struktur miejskich na tle różnorodności stylów życia codziennego właściwych społeczności żydowskiej w obszarze Polski centralnej oraz zrozumienia ich roli w procesie budowy miast.

\section{Podziękowania}

Niniejszy referat podsumowuje rezultaty badania finansowanego przez Narodowe Centrum Nauki w Krakowie (UMO-2011/03/D/HS3/01630), zatytułowanego: “Analiza morfologiczna struktur miejskich w ujęciu kulturowym - społeczności żydowskie w wybranych miejscowościach województw: łódzkiego i mazowieckiego. Studium przypadku.” 


\section{Literatura}

[1] Hanzl M. Morphological analysis of urban structures - the cultural approach. Case studies of Jewish communities in Lodz and Mazovian voivoideships. Wydawnictwo Politechniki Łódzkiej, Łódź w druku.

[2] Perinbanayagam R.S. The definition of the situation: an analysis of the ethnomethodological and dramaturgical View. The Sociological Quarterly 15 (1974) 521-541.

[3] Hall E.T. Beyond culture. Anchor Books, New York 1989.

[4] Goffman E. The presentation of self in everyday life monograph. University of Edinburgh, Social Science Research Centre, Edinburgh 1959.

[5] Koter M., Kulesza M. The study of urban form in Poland. Urban Morphology 14(2) (2010) 111-120.

[6] Conzen M.R.G. The use of town plans in the study of urban history, [w] The Study of Urban History. (ed. Dyos, H. J.) Edward Arnold, London 1968, 113-30.

[7] Dziewoński K. Zagadnienie typologii morfologicznej miast w Polsce. Czasopismo Geograficzne 33(4) (1962) 41-56.

[8] Gołachowski S. Studia nad miastami i wsiami śląskimi. Państwowe Wydawnictwo Naukowe, Instytut Śląski Opole 1969.

[9] Pudełko J. Rynki w planach miast śląskich. Kwartalnik Architektury i Urbanistyki 4(3-4) (1959) 56-69.

[10] Pudełko J. Próba pomiarowej metody badania planów niektórych miast średniowiecznych w oparciu o zagadnienie działki. Kwartalnik Architektury i Urbanistyki 9(1) (1964) 3-27.

[11] Koter M. Relikty osadnictwa średniowiecznego w planie współczesnej Łodzi. Przegląd Geograficzny 48 (1976) 667-687.

[12] Kulesza M. Zagadnienia morfogenezy i rozplanowania miast średniowiecznych $w$ Polsce. Wydawnictwo Ibidem, Łódź 2011.

[13] Koter M. Rozwój układu miejskiego Łodzi wczesno-przemysłowej. Miscellanea Łódzkie, Myśl urbanistyczna a rozwój przestrzenny Łodzi 1 (1984) 54-82.

[14] Whitehand J.W.R., Larkham P.J. The urban landscape: issues and perspectives, [w] Urban landscapes international perspectives (ed. J.W.R. Whitehand \& P.J. Larkham). Routledge, London, New York 2000.

[15] Vernez-Moudon A. Urban morphology as an emerging interdisciplinary field. Urban Morphology 1 (1997) 3-10.

[16] Gauthier P., Gilliland J. Mapping urban morphology: a classification scheme for interpreting contributions to the study of urban form. Urban Morphology 10(1) (2006) 41-50.

[17] Rossi A. The Architecture of the City. The MIT Press, Cambridge, London 1984.

[18] Darin M. The study of urban form in France. Urban Morphology 2 (1998) 63-76.

[19] Panerai P., Depaule J.C., Demorgon M. Analyse urbaine. Édition Parenthèses, Marseille 2009.

[20] Lavedan P. Histoire de l'urbanisme. Antiquité, Moyen-Age. Henri Laurens, Paris 1926.

[21] Lavedan P. Histoire de l'urbanisme. La Renaissance et les Temps modernes. Henri Laurens, Paris 1941.

[22] Lavedan P. Histoire de l'urbanisme. L'Epoque moderne. Henri Laurens, Paris 1952.

[23] Poëte M. Une vie de cité. Paris de sa naissance à nos jours. Picard, Paris 1924-1931.

[24] Booth C. On the City: Physical Pattern and Social Structure. Selected Writings (ed. H.W. Pfautz). The University of Chicago Press, Chicago and London 1967.

[25] Cervellati P.L., Scannavini R., de Angelis C. La nuova cultura delle città, la salvaguardia dei centri storici, la riappropriazione sociale degli organismi urbani e l'analisi dello sviluppo territoriale nell'esperienza di Bologna. Edizioni scientifiche e tecniche Mondadori, Milano 1977.

[26] Bandini M. Some architectural approaches to urban form, [w] Urban landscapes international perspectives (ed. J.W.R. Whitehand, P.J. Larkham). Routledge, London 2000, 133-169.

[27] Eco U. Function and sign: the semiotics of architecture, [w:] Rethinking architecture: a reader in cultural theory. (ed. W.N. Leich). Routledge Taylor \& Francis Group, London 1997, 182-202. 
[28] Hillier B., Hanson J. The social logic of space. Cambridge University Press, Cambridge 1984.

[29] Marshall S. Cities, design and evolution. Routledge, Abingdon, New York 2009.

[30] Rapoport A. The meaning of the built environment. A nonverbal communication approach. The University of Arizona Press, Tuscon 1990.

[31] Lynch K. The image of the city. The MIT Press, Cambridge 1960.

[32] Kantarek A.A. Morfologia i typologia formy urbanistycznej, [w] Wyznaczniki ksztaltu wspótczesnej przestrzeni urbanistycznej (ed. A. A. Kantarek). Kraków 2015, 155-166.

[33] Portugali J. Complexity theory as a link between space and place. Environment and Planning A 38(4) (2006) 647-664.

[34] Hanzl M. Jewish neighbourhoods in prewar Poland - an attempt at typology, [w] Architectural research addressing societal challenges (ed. M.J. Rodrigues Couceiro da Costa et al.) CRC Press, Taylor \& Francis Group, Boca Raton, FL, 2017, 425-432.

[35] Wodziński M. Space and spirit: on boundaries, hierarchies and leadership in Hasidism. Journal of Historical Geography 53 (2016) 63-74.

[36] Dynner G. Yankel's tavern Jews, liquor, and life in the Kindgdom of Poland. Oxford University Press, New York 2014.

[37] Wodziński M. Żydzi w okresie zaborów, [w] Atlas historii Żydów polskich (ed. W. Sienkiewicz). Demart SA, Warszawa 2010, 155-246.

[38] Eisenbach A. Z dziejów ludności żydowskiej w Polsce w XVIII i XIX wieku: studia i szkice. Państwowy Instytut Wydawniczy, Warszawa 1983.

[39] Skorowidz miejscowości Rzeczypospolitej Polskiej opracowany na podstawie wyników Pierwszego Powszechnego Spisu Ludności z dn. 30 września 1921 r. i innych źródeł urzędowych, Warszawa: Główny Urząd Statystyczny Rzeczypospolitej Polskiej 1925, http://mbc.cyfrowemazowsze.pl.

[40] Hall E.T. Hidden Dimension. Doubleday, Garden City, NY 1966.

[41] Piechotka M., Piechotka K. Oppidum Judaeorum Żydzi w przestrzeni miejskiej dawnej Rzeczypospolitej. Krupski i S-ka, Warszawa 2004.

[42] Vilagrasa I.J. Recent change in two historical city centres: an Anglo-Spanish comparison [w] Urban Landscapes International Perspectives (eds. J.W.R. Whitehand, P.J. Larkham). Routledge, London 2000, 266-298.

[43] Hall E.T. Proxemics. [w] The anthropology of space and place, locating culture (ed. S.M. Low, D.L. Lawrence-Zuniga). Blackwell Publishing, Oxford 2009, 51-73.

[44] Hillier B. The genetic code for cities - is it simpler than we thought? [w] Complexity Theories of Cities have come of Age (ed. J. Portugali et al.). Springer-Verlag, Berlin, Heidelberg 2012.

[45] Bourdieu P. Esquisse d'une théorie de la pratique. Précédé de Trois études d'ethnologie kabyle. Librarie Droz., Paris 1972.

\section{Perception of focal places in the cultural approach. Case study of districts inhabited by Jews in prewar central Poland}

\section{Malgorzata Hanzl}

Institute of Architecture and Town Planning, Lodz University of Technology,e-mail: mhanzl@p.lodz.pl

Abstract: Perception of urban space differs according to the addressee group. In order to examine meanings assigned to urban structures and ways how space is used by differ- 
ent cultures, the current elaboration uses a method based on analyses of urban morphology, anthropology and cultural studies. The case study refers to relations between forms of neighbourhoods inhabited in the prewar times by Jewish communities and aspects of their everyday lives. While the diversity of lifestyles of the community of Polish Jews was at the time striking, some features may be clearly identified, especially when referring to its traditional faction. These features were clearly reflected by the forms of urban structures, in the neighbourhoods where Jews lived. Three primary spheres of social life were related to the three essential areas of Jewish life: religious, domestic and professional. These fields determined specific ways of spatial organisation of urban fabric, especially inside urban blocks. The forms of internal connections inside and between blocks of development may be noticed regardless the formal layout of plans of towns and villages, where Jewish communities lived.

Keywords: Urban morphology, anthropology, public space, Jewish culture. 
